\title{
Various Level of Aggressive Behavior of Schizophrenia as a Basis of Criminal Responsibility
}

\author{
Yulia Kurniaty ${ }^{1,3 *}$, Sambodo Sriadi Pinilih ${ }^{2}$
}

\author{
${ }^{1}$ Department of Law, Universitas Muhammadiyah Magelang, Magelang, Indonesia \\ ${ }^{2}$ Department of Nursing, Universitas Muhammadiyah Magelang, Magelang, Indonesia \\ ${ }^{3}$ Candidate Doctor of Law, Universitas Islam Indonesia Yogyakarta, Yogyakarta, Indonesia \\ *Corresponding author.Email: yuliakurniaty@ummgl.ac.id
}

\begin{abstract}
The purpose of this study is to determine the various levels of aggressive behaviour in the form of motor and emotional activity in schizophrenics that affect cognitive abilities and perceptions, as a basis for objective consideration of law enforcement officials to determine whether the offender is capable of being responsible or not. The research method is paradigm of the principle of guilty in criminal liability. Data were obtained from law books and psychiatric nursing, journals of laws and psychiatric nursing, and Judge's Decision. The results showed that schizophrenics have aggressive behaviour problems due to impaired cognitive abilities and perceptions, thus affecting the ability to make decisions, distinguish right from wrong, and recognize himself. The instrument used to evaluate patients was PANSS-EC, based on this instrument there were five different degrees of schizophrenia, namely mild, moderate, somewhat severe, severe and very severe. If the patient falls into the category of mild and moderate then he can be asked for criminal responsibility, if the patient is categorized as rather severe then he can be asked for criminal responsibility only that the pain can be a reason to reduce the penalty, if the patient is categorized as severe and very severe then he cannot be asked criminal liability, and should undergo rehabilitation.
\end{abstract}

Keywords: schizophrenia, impaired cognition and perception, criminal responsibility

\section{INTRODUCTION}

The study of criminal liability by schizophrenics is not new, but until now it is still an interesting topic to be discussed because it is still occurring. Criminal cases committed by ODS mutilation with the defendant Pupun Bin Sanusi who killed and mutilated the victim named Ny. Anih Bint Komar is also her own biological mother [1]. During the trial the Public Prosecutor presented 3 (three) psychiatric expert witnesses who in their examination stated that the Defendant had psychotic disorders in the form of paranoid type schizophrenia, so the Judge imposed rehabilitation[2]. As for the fraud case with the defendant JMLS who was diagnosed with Bipolar, he was still sentenced to 1 year 10 months imprisonment [3].

Schizophrenia is a persistent and serious brain disease that results in psychotic behavior, concrete thinking and difficulties in processing information, interpersonal relationships and problem solving [4]. Various factors cause schizophrenia such as genetic problems, viruses, auto antibodies and malnutrition [5]. Efforts to overcome the frequency of recurrence have been carried out by mental health staff in collaboration with families of sufferers in the form of assistance and supervision of adherence in taking medicine for schizophrenics, as well as forming communities that care about people with mental disorder to educate its citizens playing an active role in maintaining a conducive environmental situation so as not to triggers sufferers to commit criminal acts [6].

In several health journals, the majority of researchers take the factors causing a person suffering from schizophrenia as the object of the study. In Aceh, researchers emphasize that spiritual and psychosocial factors are the cause [7]. In DIY, factors that influence the incidence of readmission are medication adherence and the role of caregivers [8]. For Bengkulu, the factors causing schizophrenia are genetic, psychosocial and environmental [9]. Whereas in Bogor, the causes are biological, psychological and social factors [10]. As for several legal journals, the discussions regarding criminal liability for schizophrenics still focus on Article 44 paragraph (1) of the Criminal Code. Juridical analysis studies of schizophrenics who kill are enriched by making comparisons with The Draft of Criminal Code [11]-[13], reasons for eradicating crimes for schizophrenics who kill [14], disparities in judges' decisions for schizophrenics [15], psychopathic criminal liability [16], and appropriate legal sanctions for criminal behavior by people with mental disorders [17].

Completing the study, the authors review the characteristics of schizophrenic aggressive behavior as a basic for assessing whether he can think logically, distinguish the right or wrong and realize whether his actions are breaking the law or not. The purpose of this study is to determine the level of aggressive behavior in the form of motoric and emotional activities which affects to ability of cognition and perception, as a basic for objective consideration of law enforcement officials in determining whether the offender is able to take responsibility or not. 


\section{RESEARCH METHODS}

The research method was carried out by means of a literature study. Data were obtained from a criminal law book that reviews about being able to be responsible as an element of the principle of error, and nursing book that reviews the level of aggressive behavior in the form of motoric and emotional activity which affects to ability of cognition and perception; articles published in legal journals, health journals and nursing journals that examined the legal liability of people with mental disorder, the factors causing mental disorders and efforts to overcome them. The data obtained were then analyzed using qualitative methods and presented in descriptive form.

\section{RESULTS AND DISCUSSION}

\subsection{The Elements of Guilty in Criminal Liability}

In terms of criminal conviction, Indonesia adheres to monodualistic understanding, this understanding separates the elements of criminal responsibility into two aspects, namely the objective and subjective elements. The objective element is to examine the actions that are prohibited from being carried out. The subjective element examines the mistakes that must exist in the perpetrators [18].

The principle of error means no crime without error, it is known in various terms such as Keine Strafe ohne Schuld; Geen Straf Zonder Schuld; Nulla Poena Sine Culpa [18]. In his book, Moeljatno added another term namely actus non facit reum nisi mens sit rea [19]. Regarding this error, it is certainly related to whether there is freedom of the will from the perpetrators. Regarding freedom of the will, the Criminal Code adheres to the concept of indeterminism which asserts that humans have free will and this is the cause of all volitional decisions. If there is no free will then there is no mistake so there is no reproach, for that then there is no punishment[18]. Defamation in this matter is related to ethics (ethische schuld) and denigration based on applicable law (verantwoordelijkheid rechtens) [18].

Discussing the principle means that it will not be separated from the study of the relationship in relation to behavior, in this case divided into two kinds, namely intentional (dolus) and negligence (culpa). If the inner relationship involves wanting to take action to avoid that action, then it is categorized as dolus. However, in neglect the attitude of the mind does not want to do an action and also does not want to occur because of that action [18].

Thus, three criminal law experts agree that the elements of error contain at least three things, namely: 1) the ability to be responsible (toerekeningsvatbaarheid) the person who committed the act; 2) certain inner relationships of people who carry out actions in the form of dolus or culpa; 3 ) there is no reason for error eradication/forgiveness (schuld ontbreekt) [20].

\subsection{The Element of the Perpetrator's Mental State in Criminal Liability}

The core of being able to take responsibility lies in the state of mind/mentality of a person who is healthy when committing a crime. Article 44 paragraph 1 of the Criminal Code states, "Whoever commits acts that cannot be accounted for because his soul is handicapped in growth or disrupted by disease, cannot be convicted" [21]. The original text in Dutch is niet strafbaar is hij die een feit begaat dat hem wegenade gebrekkige ontwikkeling of ziekelijke storing zijner verstandelijke vermogens niet right worden toegerekend [18]. Based on the explanation, the meaning is able to be responsible if it meets the qualifications: 1) The ability to differentiate between good and bad deeds; in accordance with the law or that is against the law; 2) The ability to do his will according to his conviction about his good and bad actions [19].

The system used by the Criminal Code to prove the mental state of disabled and disturbed perpetrators due to disease is descriptive normative. Descriptive verification is carried out by psychiatrists while normative verification is carried out by judges [18]. The psychiatrist will conduct a series of examinations to find whether there is a defective mental state in the perpetrators. The judge will examine whether the perpetrator's actions meet the elements of offense or not. Furthermore, the judge will use the results of the psychiatric examination as a basic for consideration to impose sanctions or not.

\section{Measuring the Severity of Schizophrenia Patients Using the PANSS-EC Instrument}

PANSS-EC is an instrument used to evaluate patients with aggressive behavior or agitation. This instrument was first introduced by Stanley Kay, Lewis Opler, and Abraham Fiszbein in 1987 [22]. The types of psychiatric disorders that are evaluated are those that have the potential to appear aggressive or agitating, namely depression, schizophrenia or alcoholism. The components assessed are 5 (five) behaviors which include rowdy, tension, hostility, noncooperation and impulse control. Each of these behaviors is assessed on a scale of numbers 1-7, if the evaluation results are on a scale of 1 it means that no symptoms of aggressive/agitation are found (the patient has no psychiatric disorders); Scale 2 shows patients suffering from minimal but pathologically doubtful symptoms; Scale 3 means the patient has mild psychiatric disorders; Scale 4 shows the patient has a moderate psychiatric disorder; Scale 5 shows the patient has a rather severe psychiatric disorder; Scale 6 shows that the patient has severe psychiatric disorders. Scale 7 shows that the patient has very severe psychiatric disorders [23]. The total value of the 5 behaviors above is $5-35$, if the patient evaluation results are in the number $25-35$ then it requires medical intervention or treatment in the hospital [24]. 
[5] Iyus Yosep, Keperawatan Jiwa, 3rd ed. Bandung: PT. Refika Aditama, 2010.

[6] S. S. Pinilih, R. T. Astuti, and M. K. Amin, "Manajemen Kesehatan Jiwa Berbasis Komunitas Melalui Pelayanan Keperawatan Kesehatan Jiwa Komunitas Di Wilayah Dinas Kesehatan Kabupaten Magelang," The 2nd University Research Coloquium, 2015 .

[7] Sri Novitayani, "Penyebab Skizofrenia Pada Pasien Rawat Jalan Di Aceh," Idea Nursing Journal, vol. VIII, no. 3, 2017.

[8] S. H. Pratiwi, C. R. Marchira, and Julita Hendrartini, "Faktor-Faktor Yang Mempengaruhi Rawap Inap Ulang Pasien Skizofrenia Pada Era Jaminan Kesehatan Nasional Di Rumah Sakit Grhasia Pemda DIY," Kebijakan Kesehatan Indonesia, vol. 6, no. 1,2017

[9] D. Hermiati and Resnia Madona Harahap, "Faktor Yang Berhubungan Dengan Kasus Skizofrenia Pada Pasien Rawat Inap Rumah Sakit Khusus Jiwa Soeprapto Provinsi Bengkulu," Jurnal Keperawatan Silampari, vol. 1, no. 2, 2018.

[10] F. Rinawati and Moh Alimansur, "Analisa FaktorFaktor Penyebab Gangguan Jiwa Menggunakan Pendekatan Model Adaptasi Stres Stuart," Jurnal Ilmu Kesehatan, vol. 5, no. 1, 2016.

[11] Alifah Aminatuz Zahro, E. Soponyono, and Purwoto, "Analisis Yuridis Terhadap Tindak Pidana Pembunuhan Yang Dilakukan Oleh Orang Dengan Gangguan Jiwa (Skizofrenia) (Studi Kasus: Putusan Mahkamah Agung Nomor 125 K/Pid/2012)," Universitas Diponegoro Semarang, 2017.

[12] N. M. R. P. P. Sugama and S. Putrawan, “Analisis Yuridis Mengenai Kemampuan Pertanggungjawaban Pidana Dalam Pasal 44 KUHP," Jurnal Kertha Wicara, vol. 7, no. 4, 2018.

[13] M. N. Fajri, I. B. S. D. Jaya, and I. G. N. Parwata, "Kebijakan Hukum Pidana Indonesia Terhadap Tindak Pidana Yang Dilakukan Oleh Pengidap Skizofrenia," Jurnal Kertha Wicara, vol. 6, no. 4, 2017.

[14] Emilifia, F. Fitri, N. Rochaeti, and R. Sularto, "Penghapusan Pidana Bagi Pelaku Pembunuhan Yang Mengidap Skizofrenia (Analisis Putusan No 144/PID.B/2014/PN.CJ)," Universitas Diponegoro Semarang, 2017.

[15] I. P. Susanto, Yuliati, and Fines Fatimah, "Disparitas Putusan Hakim Dalam Penjatuhan Sanksi
[4] Gail W.Stuart, Buku Saku Keperawatan Jiwa, 5th ed. Jakarta: EGC, 2006. 
Pidana Terhadap Pelaku Tindak Pidana Oleh Pengidap Gangguan Kejiwaan,” Jurnal Hukum, no. Juli, 2018.

[16] E. S. Yudhiati, E. Effendi, and Ledy Diana, "1JOMFakultas Hukum Volume III Nomor IFebruari 2016.Tinjauan Yuridis Terhadap Pertanggungjawaban Pidana Bagi Seorang Psikopat Dalam Tindak Pidana Pembunuhan," Jurnal Online Mahasiswa Fakultas Hukum Universitas Riau, vol. 3, no. 1, 2016.

[17] Adriesti Herdaetha, "Pertanggungjawaban Kriminal Orang Dengan Gangguan Jiwa,” Jurnal Jurisprudence, vol. 5, no. 1, 2015.

[18] Sudarto, Hukum Pidana I, 2nd ed. Semarang: Yayasan Sudarto, Fakultas Hukum Universitas Diponegoro, 1990.

[19] Moeljatno, Asas-Asas Hukum Pidana. Jakarta: PT Rineka Cipta, 2000.

[20] Bambang Poernomo, Asas-Asas Hukum Pidana, VII. Jakarta: Ghalia Indonesia, 1994.

[21] Soenarto Soedibroto, KUHP dan KUHAP Dilengkapi Dengan Yurisprudensi Mahkamah Agung dan Hoge Raad, 3rd ed. Jakarta: PT. RajaGrafindo Persada, 1996.

[22] Wikipedia, "Positive and Negative Syndrome Scale."

[23] dr. Irwan Supriyanto PhD SpKJ, "Cara Menggunakan PANSS-EC untuk Pasien Agitasi,” 2019.

[24] Yuyun Yulianti, “Cetak Biru Pelayanan Pasien di Rumah Sakit Jiwa Provinsi Jawa Barat Tahun 2014,” Jurnal ARSI, 2015. 